\title{
Bis-pyrazolylpyridine Complexes of Some Transition Metal Ions: Structure-Activity Relationships and Biological Activity
}

\author{
Ana Rilak Simović, ${ }^{a}$ Jovana Bogojeski, $^{\mathrm{b}}$ Biljana Petrović, ${ }^{\mathrm{b}}$ \\ and Snežana Jovanović-Stevića@
}

This review is dedicated to Professor Rudi van Eldik on the occasion of his 75th birthday

${ }^{a}$ University of Kragujevac, Institute for Information Technologies Kragujevac, Department of Natural Science, Jovana Cvijića bb, 34000 Kragujevac, Serbia

${ }^{\mathrm{b}}$ University of Kragujevac, Faculty of Science, Radoja Domanovića 12, 34000 Kragujevac, Serbia

${ }^{\circledR}$ Corresponding authorE-mail: snezanaj@kg.ac.rs

\begin{abstract}
In this review we summarize our work on development of metallocomplexes with pincer type ligands such as bis-pyrazolylpyridine and its camphor derivatives. The review focuses on the correlation between the kinetics reactivity, DNA/ protein interactions and cytotoxicity of these metallocomplexes. In order to establish the structure-activity relationship for the metal-based drugs, we have designed, synthesized and thoroughly studied the complexes with several transition metal ions: Pt(II), Pd(II), Au(III) and Rh(III). The first part of the present review is focused on the kinetic study of the ligand substitution reactions of complexes with small biomolecules (5'-GMP and some amino acids). The second part of the review is about DNA/BSA interactions of these complexes and last part is about cytotoxicity of Pt(II), Pd(II), Au(III) and Rh(III) complexes on different cell lines. Systematic summary of these results will contribute to the future development of transition metal ion complexes as potential antitumor agents and will have importance to understand the potential toxicity of metal-based drugs.
\end{abstract}

Keywords: Metal complexes, kinetics, DNA/BSA interactions, cytotoxicity.

\section{Комплексы бис-пиразолилпиридина с ионами некоторых переходных металлов: взаимосвязь структура-активность и биологическая активность}

\author{
А. Р. Симович, ${ }^{a}{ }^{a}$ ж. Богойески, ${ }^{\mathrm{b}}$ Б. Петрович, ${ }^{\mathrm{b}}$ С. Йованович-Стевич ${ }^{\mathrm{a} @}$ \\ ${ }^{\mathrm{a}}$ Кафедра науки, Институт информаџионных технологий, Крагуеваџкий университет, 34000 Крагуеваи, Сербия \\ ${ }^{\mathrm{b}}$ Факультет наук, Крагуеваџкий университет, 34000 Крагуеваи, Сербия \\ @E-mail: snezanaj@kg.ac.rs
}

\begin{abstract}
В обзоре подведень итоги работы авторов по созданию металлокомплексов с лигандами пинцерного типа, такими как бис-пиразолилпиридин и его камфорапроизводные. Основное внимание уделяется корреляиии между реакиионной способностью, взаимодействиями ДНК/белок и ичитотоксичностью этих металлокомплексов. Для установления взаимосвязи структура-активность для лекарственных препаратов на основе металлов мы разработали, синтезировали и тщзательно изучили комплексы с несколькими ионами переходных металлов:

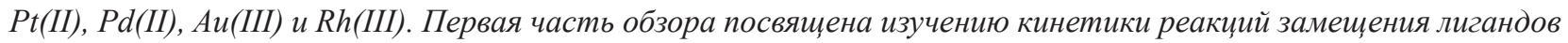
в комплексах с небольшими биомолекулами (5'-ГМФ и некоторыми аминокислотами). Во второй части рассматривается взаимодействие этих комплексов с ДНК/БСА, а последняя часть посвящена изучению циитотоксичности комплексов Pt(II), Pd(II), Аи(III) и Rh(III) на различных линиях клеток. Систематическое обобщение этих результатов способствует развитию потенциала использования комплексов ионов переходных
\end{abstract}


металлов в качестве противоопухолевых препаратов и имеет важное значение для понимания возможной токсичности металлсодержащих лекарственньх средств.

Ключевые слова: Металлокомплексы, кинетика, ДНК/БСА взаимодействие, цитотоксичность.

\section{Introduction}

Transition metal complexes are nowadays used all over the world in medicine for the treatment of many diseases due to the different mechanism of action. ${ }^{[1]}$ The discovery of cisplatin, cis- $\mathrm{Pt}\left(\mathrm{NH}_{3}\right)_{2} \mathrm{Cl}_{2}$, as an antineoplastic agent has focused attention on the rational design of metal complexes that can be used in cancer therapy. ${ }^{[2]}$ Over the past decades, numerous Pt-complexes have been designed and evaluated as antitumor agents. ${ }^{[3]}$ Among them, only few of them entered clinical trial and today are successfully use in the treatment of various types of cancers, such as testicular, ovarian, bladder, colon, head and neck, and small-cell lung cancers. ${ }^{[4]}$ However, serious side effects as emesis, nephrotoxicity, neurotoxicity, ototoxicity and drug resistance, are connected with clinical application of cisplatin.

Today it is generally accepted the fact that major pharmacological target of Pt-antitumor agents is cellular DNA. $[5,6]$ There are different ways for the metal complex-DNA coordination. ${ }^{[7]}$ However, the most accessible site as well as the most reactive nucleophilic site for metal binding is N7 atom of guanine, located in the major groove of the double helix of DNA. ${ }^{[8]}$ The main product that is formed during interaction of cisplatin with DNA is a bidentate 1,2-intrastrand cross-link, in which cis- $\left[\mathrm{Pt}\left(\mathrm{NH}_{3}\right)_{2}\right]^{2+}$ undergoes cross-linkage between two adjacent guanine N7-atoms. [9] Other coordination modes, for example, interstrand cross-links or monofunctional DNA-binding, are less frequent. Thus, formed 1,2-intrastrand cross-link adducts are recognized by a variety of proteins, which results either in their stabilization or DNA repair. Platination of DNA after cellular processing disrupts the tertiary structure of DNA and thus inhibits its replication and transcription. ${ }^{[10]}$

However, Pt-complexes can also interact with other biomolecules present in the cell. These are primarily sulfurcontaining molecules, i.e. thiols and thioethers, which have a very high affinity towards platinum. ${ }^{[5,7]}$ Glutathione (GSH), $L$-cysteine ( $L$-cys), $L$-methionine ( $L$-met) and many other sulfur-donor ligands play an important role in the metabolism of cisplatin and its analogues. A generally accepted hypothesis is that the Pt-complex initially binds to sulfur-donor ligands, which is a kinetically favored process, and then convert to platinum-DNA adduct, thermodynamically more stable product. ${ }^{[1]} \mathrm{Pt}-\mathrm{S}$ (thioether) product, that is formed during the interaction of cisplatin and $L$-met, is labile towards DNA, i.e. thioether from the coordination sphere may be substituted by the N7 atom of guanosine$5^{\prime}$-monophosphate (5'-GMP). So, it is believed that Pt$\mathrm{S}$ (thioether) is suitable intermediate for the interaction of cisplatin and DNA. On the other hand, Pt-S(thiol) is very stable product and it can be decomposed in the presence of compounds known as "rescue agents", which are exclusively sulfur-containing compounds, such as diethyldithiocarbamate (DEDTC), thiourea (tu), GSH, $L$-cys and biotin. It is assumed that these interactions are associated with toxic side effects that occur in the body during the chemotherapy. For these reasons, many research groups have focused their studies on the kinetic and mechanistic behavior of structurally different $\mathrm{Pt}(\mathrm{II})$ complexes through their substitution reactions with sulfur- and nitrogen-donor biomolecules. The obtained results are important for understanding the toxicity and antitumor activity of related platinum complexes. In addition, they can contribute to the development of new Pt-based drugs with enhanced antitumor activity and with fewer side effects. ${ }^{[12]}$

Furthermore, a huge need towards the drugs with antiproliferative activity of improved properties has led to the synthesis of non-platinum drugs. Such, numerous drugs based on palladium, ${ }^{[13-15]}$ gold, ${ }^{[16]}$ ruthenium, ${ }^{[17]}$ rhodium, ${ }^{[18]}$ etc., were studied as potential platinum replacements. One of the greatest interests for the development of the $\mathrm{Pd}(\mathrm{II})$ complexes as anticancer agents is based on similar coordination chemistry of $\mathrm{Pt}(\mathrm{II})$ and $\mathrm{Pd}(\mathrm{II})$ compounds.$^{[7]}$ Because, many Pd(II) complexes are often used as model molecules to test the kinetics and mechanism of the substitution reactions with biomolecules. Unlike the Pt compounds, they react too fast producing very reactive species that are unable to reach their pharmacological targets. In order to achieve greater activity of the drug based on the palladium, it is necessary to stabilize it by bulky chelating ligand which can reduce its reactivity and unwanted side effects. On this way, many Pd(II) complexes were synthetized with comparable or even with better antitumor activity than the cisplatin in vitro. ${ }^{[15]}$ There are a number of studies in the chemistry of $\mathrm{Pt} / \mathrm{Pd}$ complexes that have shown promising results in the field of anticancer chemistry, indicating that the biological activity of these complexes can be influenced by variation of their carrier ligands. Significant advances have emerged from this aspect of design.

Another important aspect that should be considered during the design of effective anticancer drugs is their ability to be transported to the target site. The most abundant carrier proteins are serum albumins (SA) that have an important role in the transportation and deposition of many biologically active compounds in the circulatory system. Therefore, studies on the binding properties of biologically active compounds toward these macromolecules can provide very useful information about therapeutic effectiveness of drugs. ${ }^{[19]}$

Among the several metals other than platinum, gold compounds have gained increasing attention in the design of new metal-based anticancer therapeutics. ${ }^{[20,21]}$ The mechanism of action of anticancer Au-complexes is largely unknown. At the beginning of the research, the DNA was considered to be the biological target, but later studies showed that thiol-containing proteins/enzymes, such as thioredoxin reductase (TrxR), can play important roles in their mechanism of action. ${ }^{[22]}$ It was demonstrated that some 
$\mathrm{Au}(\mathrm{III})$ complexes showed high cytotoxicity against solid cancer tumors in vitro and in vivo causing minimal systemic toxicity. ${ }^{[23,24]}$ In the present review we have included a short report of the chemistry and reactivity of novel $\mathrm{Au}$ (III) pincer type complexes. One of the major challenges for the medical development of $\mathrm{Au}$ (III) complexes is their stability in aqueous solutions. The investigation of new Au-complexes<smiles>Cn1nc(C2=CC=CC3=C4C=CNN4[P-](Cl)(Cl)N23)cc1C(C)(C)C</smiles>

1<smiles>Cn1nc(C(C)(C)C)cc1C1=CC=CC2=C3C=C(C(C)(C)C)NN3[P-](Cl)N12</smiles>

3<smiles></smiles>

5

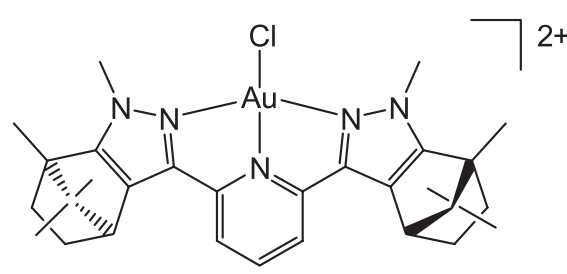

7

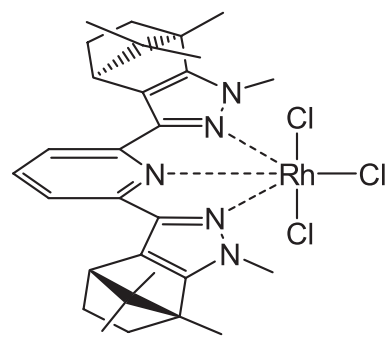

showed that they have a good potential to overcome the cisplatin resistance problem.

Since Rosenberg' ${ }^{[1]}$ discovery to today intensive investigations showed that, except Pt(II) complexes, ruthenium metal-drugs exhibit very good properties as anti-tumor drugs, but none of them were ever used in clinical practice. ${ }^{[25-27]}$ Such knowledge lead us to search toward metal<smiles></smiles>

2<smiles></smiles>

4<smiles></smiles>

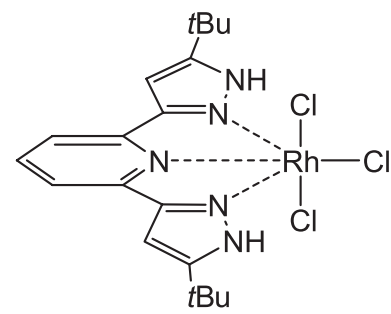

8

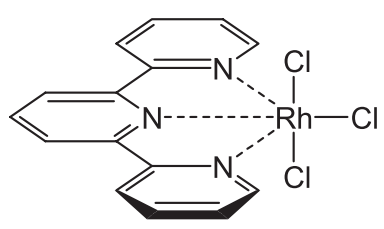

10

$\left[\mathrm{Pd}\left(\mathrm{H}_{2} \mathrm{~L}^{t \mathrm{Bu}}\right) \mathrm{Cl}\right]^{+}$(1), $\left[\mathrm{Pd}\left(\mathrm{Me}_{2} \mathrm{~L}^{t \mathrm{Bu}}\right) \mathrm{Cl}\right]^{+}$(2), $\left[\mathrm{Pt}\left(\mathrm{H}_{2} \mathrm{~L}^{t \mathrm{Bu}}\right) \mathrm{Cl}\right]^{+}(\mathbf{3}),\left[\mathrm{Pt}\left(\mathrm{Me}_{2} \mathrm{~L}^{t \mathrm{Bu}}\right) \mathrm{Cl}\right]^{+}$(4), [ $\left.\mathrm{Au}\left(\mathrm{H}_{2} \mathrm{~L}^{t \mathrm{Bu}}\right) \mathrm{Cl}\right]^{2+}(\mathbf{5})$,

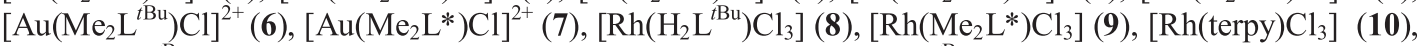
(where $\mathrm{H}_{2} \mathrm{~L}^{t \mathrm{Bu}}=2,6$-bis(5-(tert-butyl)-1H-pyrazol-3-yl)pyridine, $\mathrm{Me}_{2} \mathrm{~L}^{t \mathrm{Bu}}=2,6$-bis(5-(tert-butyl)-1-methyl1H-pyrazol-3-yl)pyridine, $\quad \mathrm{Me}_{2} \mathrm{~L}^{*}=2,6$-bis $((4 \mathrm{~S}, 7 \mathrm{R})-1,7,8,8$-tetramethyl-4,5,6,7-tetrahydro-1H-4,7methanoindazol-3-yl)pyridine, terpy $=2,2^{\prime} ; 6^{\prime}, 2^{\prime \prime}$-terpyridine)

Figure 1. Structures of the studied complexes. 
complexes containing metals such as rhodium, osmium and iridium. ${ }^{[28]}$ Because of their inertness, rhodium and osmium complexes have just recently received increasing attention. Reactivities, binding preferences and cellular uptake of these complexes strongly reliant on the combination of their ligands and the geometry of coordination. ${ }^{[29]}$ Inertness, as a specific characteristic of these metals complexes, that was in the beginning seen as a drawback, has contributed to the further design of complexes with a specific target for proteins, enzyme inhibitors, as well as DNA. ${ }^{[29]}$

Taking all above into account, here, we present our results which refer to $\mathrm{Pt}(\mathrm{II}), \mathrm{Pd}(\mathrm{II}), \mathrm{Au}(\mathrm{III})$ and $\mathrm{Rh}(\mathrm{III})$ complexes containing pincer type ligands. In this review we summarize the data obtained through the studies of the interactions of these complexes with important biological molecules such as amino acids, peptides, 5'-GMP, DNA and proteins. In addition, the results of in vitro cytotoxicity on different cancer cell lines were presented as well.

\section{Camphor-Derived bis-Pyrazolylpyridine Complexes}

Many diverse ligands are extensively used in the synthesis of complexes which could show potential activity as cytostatic. Moreover, the role of the ligand is very significant, even ligand can increase or decrease the activity of the metal ion in complex compound. We chose to use bis-pyrazolylpyridine ligands and its camphor derivatives to design a complexes of $\mathrm{Pd}(\mathrm{II}), \mathrm{Pt}(\mathrm{II}), \mathrm{Au}(\mathrm{III})$ and $\mathrm{Rh}$ (III). The used ligands are pincer type ligands with diverse substituent patterns on the pyrazolyl moiety, creating the differences in space configuration and electron density distribution that could influence on biomolecular interaction potential or cytotoxicity. In recent years, metal ion complexes containing bis-pyrazolylpyridine ligands have gained increased attention, because of their rich coordination chemistry, and a number of established and potential application areas including medicinal chemistry. ${ }^{[30,31]}$ It was demonstrated that the proper choice of ligands surrounding a metal center is crucial, as they affect the chemistry and reactivity of the complex. ${ }^{[32]}$ The structures of studied complexes are presented in the Figure 1.

\section{Substitution Reactions}

In this part of current review, we present the relation between structure and activity of complexes containing tridentate nitrogen-donor chelating system throughout substitution reactions with biologically important small biomolecules. The kinetic and mechanism of the substitution reactions of studied complexes (Figure 1) with important biological ligands such as thiourea (tu), $L$-methionine ( $L$-met), $L$-cysteine ( $L$-cys), glutathione (GSH) and guanosine-5'-monophosphate (5'-GMP) were studied. ${ }^{[33-36]}$ Some obtained results are given in the Table 1 .

The obtained results have reported a much higher reactivity of $\mathrm{Pd}$ (II) complexes compared to the corresponding $\mathrm{Pt}(\mathrm{II})$ complexes (Table 1). As palladium-based complexes
Table 1. A summary of the rates of ligand substitution reactions with 5'-GMP and $L$-met.

\begin{tabular}{|c|c|c|c|}
\hline & $\begin{array}{c}\text { 5'-GMP, } \\
k_{2}\left(\mathrm{M}^{-1} \mathrm{~s}^{-1}\right)\end{array}$ & $\begin{array}{c}L \text {-met, } \\
k_{2}\left(\mathrm{M}^{-1} \mathrm{~s}^{-1}\right)\end{array}$ & Ref. \\
\hline$\left[\mathrm{Pd}\left(\mathrm{H}_{2} \mathrm{~L}^{\mathrm{iBu}}\right) \mathrm{Cl}\right]^{+}(\mathbf{1})$ & $920 \pm 10$ & $14500 \pm 100$ & [33] \\
\hline$\left[\mathrm{Pd}\left(\mathrm{Me}_{2} \mathrm{~L}^{t \mathrm{Bu}}\right) \mathrm{Cl}\right]^{+}(\mathbf{2})$ & $810 \pm 10$ & $11800 \pm 100$ & [33] \\
\hline$\left[\mathrm{Pt}\left(\mathrm{H}_{2} \mathrm{~L}^{t \mathrm{Bu}}\right) \mathrm{Cl}\right]^{+}(\mathbf{3})$ & $0.054 \pm 0.002$ & $0.626 \pm 0.004$ & [33] \\
\hline$\left[\mathrm{Pt}\left(\mathrm{Me}_{2} \mathrm{~L}^{t \mathrm{Bu}}\right) \mathrm{Cl}\right]^{+}(\mathbf{4})$ & $0.044 \pm 0.001$ & $0.508 \pm 0.001$ & [33] \\
\hline$\left[\mathrm{Au}\left(\mathrm{H}_{2} \mathrm{~L}^{t \mathrm{Bu}}\right) \mathrm{Cl}\right]^{2+}(\mathbf{5})$ & $6800 \pm 200$ & / & [34] \\
\hline$\left[\mathrm{Au}\left(\mathrm{Me}_{2} \mathrm{~L}^{t \mathrm{Bu}}\right) \mathrm{Cl}\right]^{2+}(\mathbf{6})$ & $5300 \pm 300$ & I & [34] \\
\hline$\left[\mathrm{Au}\left(\mathrm{Me}_{2} \mathrm{~L}^{*}\right) \mathrm{Cl}\right]^{2+}(7)$ & $4400 \pm 200$ & I & [34] \\
\hline$[\mathrm{Au}(\text { terpy }) \mathrm{Cl}]^{2+}$ & $2250 \pm 30$ & I & [37] \\
\hline$\left[\mathrm{Rh}\left(\mathrm{H}_{2} \mathrm{~L}^{\mathrm{tBu}}\right) \mathrm{Cl}_{3}\right](\mathbf{8})$ & $0.41 \pm 0.01$ & $0.24 \pm 0.02$ & {$[35]$} \\
\hline$\left[\mathrm{Rh}\left(\mathrm{Me}_{2} \mathrm{~L}^{*}\right) \mathrm{Cl}_{3}\right](\mathbf{9})$ & $5.6 \pm 0.1$ & $0.38 \pm 0.01$ & [36] \\
\hline$\left[\mathrm{Rh}(\right.$ terpy $\left.) \mathrm{Cl}_{3}\right](\mathbf{1 0})$ & $0.40 \pm 0.01$ & $0.034 \pm 0.001$ & {$[36]$} \\
\hline
\end{tabular}

are more reactive compared to analogue platinum complexes $\left(10^{3}-10^{5}\right.$ times), that was expected. ${ }^{[13]}$ In addition, complexes with $\mathrm{H}_{2} \mathrm{~L}^{t \mathrm{Bu}}$ inert ligand (1 and 3) showed slightly higher reactivity than those with $\mathrm{Me}_{2} \mathrm{~L}^{\mathrm{tBu}}(\mathbf{2}$ and 4), indicating the steric influence of chelating ligands on the reactivity of complexes. That was assigned to the presence of the methyl substituent on the nitrogen atom in $\mathrm{Me}_{2} \mathrm{~L}^{t \mathrm{Bu}}$, which makes the arrival of the entering ligands to the metal center more difficult. Also, reported results confirm well established fact that sulfur-containing molecules are stronger nucleophiles than nitrogen donors. So, the following order of reactivity of the used ligands was found for the substitution reactions of studied complexes 1-4: tu $>L$-cys $>L$-met $>5^{\prime}$-GMP. ${ }^{[33]}$ Thiourea showed the highest reactivity, because it combines the ligand properties of thiolates ( $\pi$-donors) and thioethers ( $\sigma$-donors and $\pi$-acceptors). ${ }^{[5]}$ However, $L$-cys was more reactive than $L$-met due to the steric hindrance of voluminous methyl group on the sulfur atom in the molecule of thioether. Further, 5'-GMP, as nitrogen donor ligand, showed the lowest reactivity. Based on the DFT results it was showed that complexes $\mathbf{1 - 4}$ have similar stability as the analogues terpy complexes. ${ }^{[33]}$ However, it is interesting to note that terpy complexes of $\mathrm{Pt}(\mathrm{II})$ and $\mathrm{Pd}(\mathrm{II})$ do not react with thioethers, but these complexes showed significant reactivity towards $L$-met. That was explained by smaller steric effect of terminal five-membered heterocycles on the arrival of thioether to the metal center ${ }^{[33]}$ On the other hand, the reactivity of the $\mathrm{Pt}(\mathrm{II})$-terpy complex towards 5'-GMP ${ }^{[5]}$ is up to three orders of magnitude higher than the reactivity of $\mathbf{3}$ or $\mathbf{4}$ complexes (Table 1). This means that the nature of the chelating and entering ligands can greatly influence the rate of substitution reactions of the pincer-type complexes.

More recently, we focused our attention on the pincer type $\mathrm{Au}(\mathrm{III})$ complexes bearing tridentate chelating ligand such as bis-pyrazolylpyridine ligand. In order to see whether these types of ligands could enhance the kinetic reactivity of the ligand substitution reactions of $\mathrm{Au}(\mathrm{III})$ complexes with biomolecules, and also, whether these interactions improved the anticancer activity of the studied complexes, we devel- 
oped new monofunctional $\mathrm{Au}(\mathrm{III})$ complexes of the general formula $\left[\mathrm{Au}\left(N-N^{\prime}-N\right) \mathrm{Cl}\right] \mathrm{Cl}_{2}$, where $N-N^{\prime}-N=\mathrm{H}_{2} \mathrm{~L}^{t \mathrm{Bu}}$ (5), $\mathrm{Me}_{2} \mathrm{~L}^{t \mathrm{Bu}}(\mathbf{6})$ or $\mathrm{Me}_{2} \mathrm{~L}^{*}(7)$. $^{[34]}$ Figure 1 presents the structures of $\mathrm{Au}(\mathrm{III})$ pincer complexes discussed in this review.

The activation parameters and the rate constants for the ligand substitution reactions of $\mathrm{Au}(\mathrm{III})$ pincer complexes with: i) nucleoside guanosine (Guo), ii) nucleotide 5'-GMP, and iii) calf thymus (CT)-DNA were determined. ${ }^{[34]}$ The obtained values of the activation entropies $\left(\Delta S_{2}^{\neq}\right)$and activation enthalpy values $\left(\Delta H_{2}^{\neq}\right)$suggested associatively activated substitution processes and indicated that the formation of bonds is favored. Regarding to the interactions of complexes 5-7 with biomolecules Guo, 5'-GMP and CT-DNA, the rate of the reactions, $k_{2}$, could be modulated by the choice of the inert tridentate chelating ligand and by the nature of the entering ligand. The reactivity of these $\mathrm{Au}$ pincer complexes with biomolecules followed the order: 5 $\left(\mathrm{H}_{2} \mathrm{~L}^{t \mathrm{Bu}}\right)>\mathbf{6}\left(\mathrm{Me}_{2} \mathrm{~L}^{t \mathrm{Bu}}\right)>\mathbf{7}\left(\mathrm{Me}_{2} \mathrm{~L}^{*}\right)$, that can be explained by the steric hindrance and $\sigma$-donicity of the methyl substituent on the bis-pyrazolylpyridine fragment in the case of $\mathbf{6}$ and 7. ${ }^{[34]}$ The similar trend of reactivity was observed for the ligand substitution reactions of similar square-planar $\mathrm{Pt}(\mathrm{II})$ and $\mathrm{Pd}(\mathrm{II})$ pincer complexes with biomolecules. ${ }^{[33]}$

The Au(III) complexes 5-7 had a good affinity towards the studied biomolecules and the order of reactivity was: CT-DNA > Guo > 5'-GMP. All three complexes bound to CT-DNA faster than they bound to guanine derivatives, Guo and 5'-GMP, which was attributed to a higher number of binding sites on huge DNA molecules. The reactions with Guo and 5'-GMP were undoubtedly strongly related to their voluminosity, since the more sterically crowded 5'-GMP reacted up to two times slower than Guo. ${ }^{[34]}$

In 2012, Bugarčić and van Eldik reported the kinetic study of the monofunctional $\mathrm{Au}(\mathrm{III})$ complexes bearing a tridentate chelating ligand of the general formula $[\mathrm{Au}(N-N-N) \mathrm{Cl}]^{2+}$, where $N-N-N=3$-azapentane-1,5-diamine (dien) or 2,2';6',2'-terpyridine (terpy), with biologically relevant nucleophiles such as $L$-histidine ( $L$-His), inosine (Ino), inosine-5'-monophosphate (5'-IMP) and 5'-GMP. ${ }^{[37]}$ Comparing the $k_{2}$ values for the ligand substitution reactions with 5'-GMP, it can be seen that Au(III) pincer complexes with bis-pyrazolylpyridine ligands (5-7) reacted from one to two orders of magnitude faster than the $\mathrm{Au}(\mathrm{III})$ complexes with terpy or dien as a tridentate ligand, demonstrating that the nature of the tridentate chelating ligand significantly affects on the rate of the substitution reactions with monofunctional gold(III) complexes. Additionaly, the authors reported the associative mechanism for the substitution reactions of monofunctional Au-dien and Au-terpy complexes that is in accordance with the results obtained for $\mathrm{Au}(\mathrm{III})$ pincer complexes. Similar observations were reported by Bogojeski et al. for the kinetic reactivity of $\mathrm{Rh}$ (III) pincer complexes with bis-pyrazolylpyridine ligands and for Rh(III)-terpy complexes. ${ }^{[35,36]}$

In addition, we have chosen to study the same type of complexes with $\mathrm{Rh}$ (III) as metal ion, since in recent years complexes of Rh, Os and Ir have been intensively examed in relation to possible anti-tumor activity. According to the obtained data (Table 1), studied Rh(III) complexes are reactive toward all of the tested nucleophiles, with order of reactivity $5^{\prime}$-GMP $>$ GSH $>L$-met. ${ }^{[35,36]}$ Since Rh(III), unlike $\mathrm{Pt}, \mathrm{Pd}$ and $\mathrm{Au}$ complexes, are borderline hard-soft acids it was expected that they have the highest affinity for nitrogen-bonding nucleophiles, 5'-GMP. The lower reactivity of $L$-met over GSH could be due to the steric effects. Unlike Pt, Pd and Au how favor to bind to sulfur-donor nucleophiles, the Rh(III) displays the greater affinity toward the nitrogen-donor nucleophile, 5'-GMP, and it can compete with sulfur-donor nucleophiles, $L$-met and GSH. These observations are of special interest, since under biological conditions within the cell, these sulfur-donor biomolecules are present in relatively high concentrations and therefore compete with the DNA. The order of reactivity of the investigated $\mathrm{Rh}(\mathrm{III})$ complexes is such that complex with $\mathrm{Me}_{2} \mathrm{~L}^{*}$ is more reactive than complexes with terpy and $\mathrm{H}_{2} \mathrm{~L}^{t \mathrm{Bu}}$.

The studied $\mathrm{Rh}(\mathrm{III})$ complexes interact with small biomolecules in the same order of reactivity as $\mathrm{Pt}(\mathrm{II})$ complexes. It is interesting that $\mathrm{Rh}(\mathrm{III})$ complex with camphor derivative ligand $\mathrm{Me}_{2} \mathrm{~L}^{*}$ interacts faster than complex with bis-pyrazolylpyridine or terpy ligand (these two complexes interact almost with same constant). However, for the same $\mathrm{Au}(\mathrm{III})$ complexes, it has been observed that also $\mathrm{Me}_{2} \mathrm{~L}^{*}$ reacts almost similarly to the bis-pyrazolylpyridine or terpy complexes. Of course, we must consider the fact that the studied complexes of $\mathrm{Rh}(\mathrm{III})$ are octahedral complexes, while the other complexes have square-planar geometry.

Finally, we can conclude that the reactivity of the complexes with different metal ions follows the order: $\mathrm{Au}(\mathrm{III})$

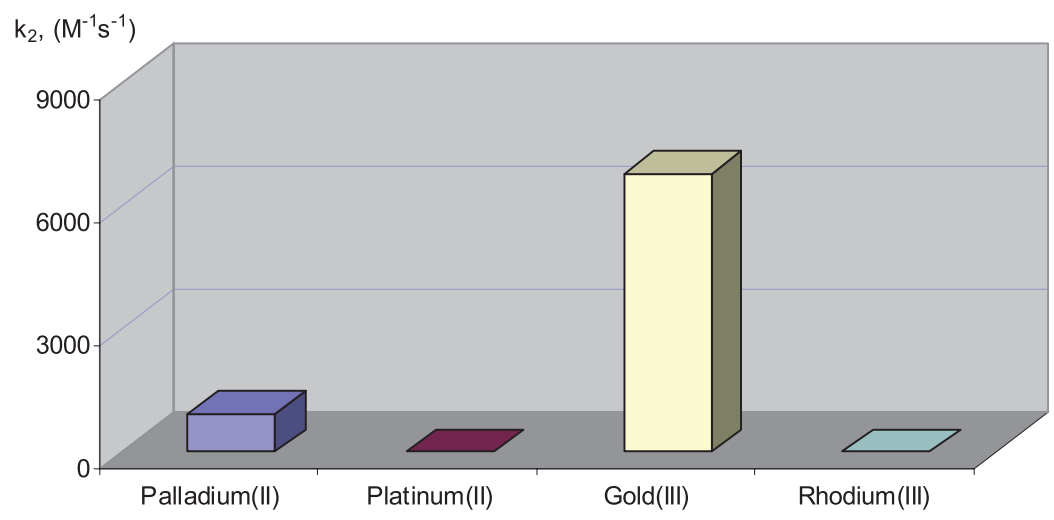

Figure 2. Comparison of $k_{2}$ constants for different transition metal ion complexes containing $\mathrm{H}_{2} \mathrm{~L}^{t B u}$ ligand. 
complexes $>\mathrm{Pd}(\mathrm{II})$ complex $>\mathrm{Rh}(\mathrm{III})$ complexes $>\mathrm{Pt}(\mathrm{II})$ complexes (Figure 2).

We believe that the research data presented herein of ligand substitution reactions can provide some insights in the possible use of kinetics studies as tools for rational design and development of metal-based antitumor drugs.

\section{Interactions with CT-DNA and BSA}

Since DNA is an important potential biological target for many metal-based anticancer complexes, it is of a great importance to understand DNA binding properties of potential anticancer agents. The transition metal complexes can bind to DNA via both covalent interaction (replacement of a labile ligand in the complex by a nitrogen base of DNA) and/or non-covalent interactions (intercalation, electrostatic or groove binding). ${ }^{[16]}$ The binding affinity of complexes shown in Figure 1 to CT-DNA and BSA was studied using by different experimental methods. ${ }^{[33-36]}$

The published results showed that the studied $\mathrm{Pd}(\mathrm{II})$ and $\mathrm{Pt}(\mathrm{II})$ complexes (1-4) have a very high binding affinity toward DNA molecule (Table 2). Pt(II) complexes exhibited much higher binding affinity than $\operatorname{Pd}(\mathrm{II})$ complexes. ${ }^{[33]}$ Additionally, the results showed that complexes containing $\mathrm{Me}_{2} \mathrm{~L}^{t \mathrm{Bu}}$ chelating ligand (2 and 4) exhibited higher binding constants than those with $\mathrm{H}_{2} \mathrm{~L}^{t \mathrm{Bu}}(\mathbf{1}$ and $\mathbf{3})$. This means that external contacts strongly influence on the strength of the studied interaction. ${ }^{[33]}$ Complexes $\mathbf{1 - 4}$ have shown the intercalation as one of the possible DNA-binding modes. The intercalating properties into DNA were also confirmed for analogue $\mathrm{Pt}(\mathrm{II})$-terpy complex. ${ }^{[38]}$ Additionally, comparing the $K_{\mathrm{b}}$ values of complexes 1-4 (the order of magnitude $10^{4} \mathrm{M}^{-1}$ ) with those published for $\mathrm{Pt}(\mathrm{II}) / \mathrm{Pd}(\mathrm{II})$-terpy complexes $\left(10^{5} \mathrm{M}^{-1}\right),{ }^{[38]}$ it can be seen that terpy complexes have a higher binding affinity to DNA. As noted above, the results of these interactions are of the great importance for evaluation of therapeutic effectiveness of the drug.

In addition, the interaction of complexes 1-4 with BSA was examined. The reported data indicate a good binding

Table 2. The obtained constants for interaction of studied complexes with CT-DNA and BSA.

\begin{tabular}{|c|c|c|c|}
\hline & $\begin{array}{c}\text { CT-DNA, } K_{\mathrm{b}}, \\
10^{4}\left(\mathrm{M}^{-1}\right)\end{array}$ & $\begin{array}{l}\text { BSA, } K, \\
10^{4}\left(\mathrm{M}^{-1}\right)\end{array}$ & Ref. \\
\hline$\left[\mathrm{Pd}\left(\mathrm{H}_{2} \mathrm{~L}^{t \mathrm{Bu}}\right) \mathrm{Cl}\right]^{+}(\mathbf{1})$ & $1.9 \pm 0.1$ & $1.9 \pm 0.1$ & [33] \\
\hline$\left[\mathrm{Pd}\left(\mathrm{Me}_{2} \mathrm{~L}^{t \mathrm{Bu}}\right) \mathrm{Cl}\right]^{+}(\mathbf{2})$ & $2.4 \pm 0.2$ & $3.2 \pm 0.2$ & [33] \\
\hline$\left[\mathrm{Pt}\left(\mathrm{H}_{2} \mathrm{~L}^{t \mathrm{Bu}}\right) \mathrm{Cl}\right]^{+}(\mathbf{3})$ & $5.3 \pm 0.1$ & $4.7 \pm 0.1$ & [33] \\
\hline$\left[\mathrm{Pt}\left(\mathrm{Me}_{2} \mathrm{~L}^{t \mathrm{Bu}}\right) \mathrm{Cl}\right]^{+}(\mathbf{4})$ & $5.5 \pm 0.1$ & $4.9 \pm 0.1$ & [33] \\
\hline$\left[\mathrm{Au}\left(\mathrm{H}_{2} \mathrm{~L}^{t \mathrm{Bu}}\right) \mathrm{Cl}\right]^{2+}(\mathbf{5})$ & $0.57 \pm 0.01$ & / & [34] \\
\hline$\left[\mathrm{Au}\left(\mathrm{Me}_{2} \mathrm{~L}^{t \mathrm{Bu}}\right) \mathrm{Cl}\right]^{2+}(\mathbf{6})$ & $0.46 \pm 0.01$ & l & [34] \\
\hline$\left[\mathrm{Au}\left(\mathrm{Me}_{2} \mathrm{~L}^{*}\right) \mathrm{Cl}\right]^{2+}(7)$ & $0.16 \pm 0.01$ & l & [34] \\
\hline$\left[\mathrm{Rh}\left(\mathrm{H}_{2} \mathrm{~L}^{t \mathrm{Bu}}\right) \mathrm{Cl}_{3}\right](\mathbf{8})$ & $9.7 \pm 0.1$ & $3.0 \pm 0.1$ & [35] \\
\hline$\left[\mathrm{Rh}\left(\mathrm{Me}_{2} \mathrm{~L}^{*}\right) \mathrm{Cl}_{3}\right](\mathbf{9})$ & $8.3 \pm 0.1$ & $3.9 \pm 0.1$ & [36] \\
\hline$[\mathrm{Rh}$ (terpy)Cl $]$ (10) & $7.0 \pm 0.1$ & $0.34 \pm 0.01$ & [36] \\
\hline
\end{tabular}

affinity of complexes to BSA $\left(10^{4} \mathrm{M}^{-1}\right)$ (Table 2). The order of activity of the tested complexes is the same as that confirmed for DNA.

To examine the binding mode of the $\mathrm{Au}(\mathrm{III})$ pincer complexes toward DNA, we have studied the interactions of complexes 5-7 with CT-DNA by UV-Vis and fluorescent spectroscopy, viscosimetry and molecular docking. The DNA-binding constants $\left(K_{\mathrm{b}}\right)$ are presented in Table 2. Our results indicated that these complexes showed a moderate binding affinity, with $\mathbf{5}$ exhibiting the highest affinity towards DNA. Combining experimental and docking results (Figure 3) it appeared that, although these three complexes had similar structures, the smallest complex $\mathbf{5}$ showed the most effective intercalation via $\pi-\pi$ stacking, which was strengthened by an additional $H$-bonding. The bullkiest complex 7 experienced the highest steric hindrance and, hence, less effective intercalation. According to the $k_{2}$ and $K_{\mathrm{b}}$ values (Table 2), it can be seen that there is a positive correlation between the kinetic reactivity and DNA interaction of the $\mathrm{Au}(\mathrm{III})$ pincer complexes. ${ }^{[34]}$ Similar observations were reported by Liu and Messori for the planar Au(III)-terpy complex which can intercalate into the DNA double helix. ${ }^{[39,40]}$ Guo and coworkers reported the in vitro cytotoxicity against several human cancer cell lines and DNA-binding affinity of four $\mathrm{Au}$ (III) complexes of the 4'-substituted terpy ligands. The results shown that DNA could be the biological target for Au(III) complexes, and the structural variation of the terpyridine derivatives may have a significant impact on their DNA binding properties. ${ }^{[4]}$ Additionaly, they demonstrated that there was a positive correlation between DNA interactions and antitumor activity of the studied complexes.

Also, we have studied the interaction of the same type of Rh(III) complexes with CT-DNA and BSA. ${ }^{[35,36]}$ The very similar order of reactivity was obtained as in case of kinetics measurements; namely UV-Vis and fluorescence spectroscopic studies both show that the complex with $\mathrm{Me}_{2} \mathrm{~L}^{*}$ interacts more strongly than terpy and $\mathrm{H}_{2} \mathrm{~L}^{\mathrm{tBu}}$. For $\mathrm{Rh}(\mathrm{III})$ complexes it was noted a somewhat higher affinity for CT-DNA than BSA, what is in agreement with obtained result from kinetic studies, where all complexes reacted faster with 5'-GMP than with sulfur-donor molecules. Complexes with $\mathrm{Me}_{2} \mathrm{~L}^{*}$ and $\mathrm{H}_{2} \mathrm{~L}^{\mathrm{tBu}}$ have reasonable affinity for BSA, while terpy displayed slightly lower affinity (Table 2 ). The terpy-Rh(III) complex appears to interact stronger with CT-DNA.

Figure 4 shows that $\mathrm{Pt}(\mathrm{II})$ and $\mathrm{Rh}(\mathrm{III})$ complexes interact significantly better compared to $\mathrm{Pd}(\mathrm{II})$ and $\mathrm{Au}(\mathrm{III})$, i.e. $\mathrm{Rh}$ (III) complexes exhibit the highest degree of interaction.

\section{In vitro Cytotoxicity}

The cytotoxic effect of complexes 1-4 on tumor cell lines HeLa (human cervix adenocarcinoma), PANC-1 (human pancreas ductal adenocarcinoma), HCT-116 (human colon cancer cell line) and healthy cell line MRC-5 (human fetal lung fibroblasts) was evaluated. All complexes showed the moderate to high cytotoxic activity (Table 3 ). In the case of $\mathrm{Pt}(\mathrm{II})$ and $\mathrm{Pd}(\mathrm{II})$ complexes, HeLa cells were more sensitive to the effects of complexes compared to PANC-1. 
Complex 5
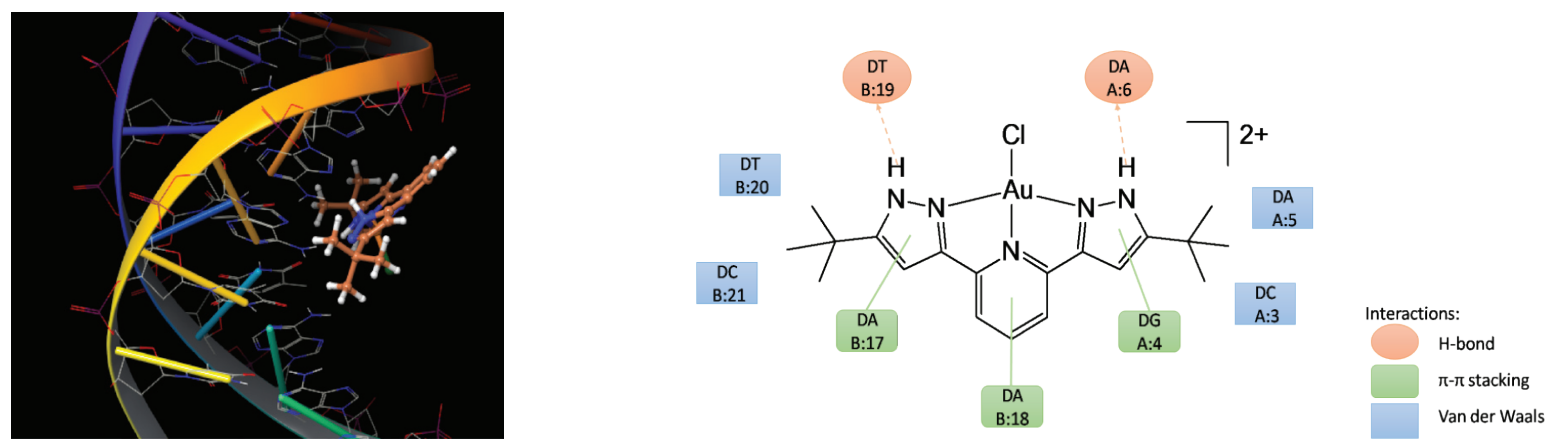

Complex 6
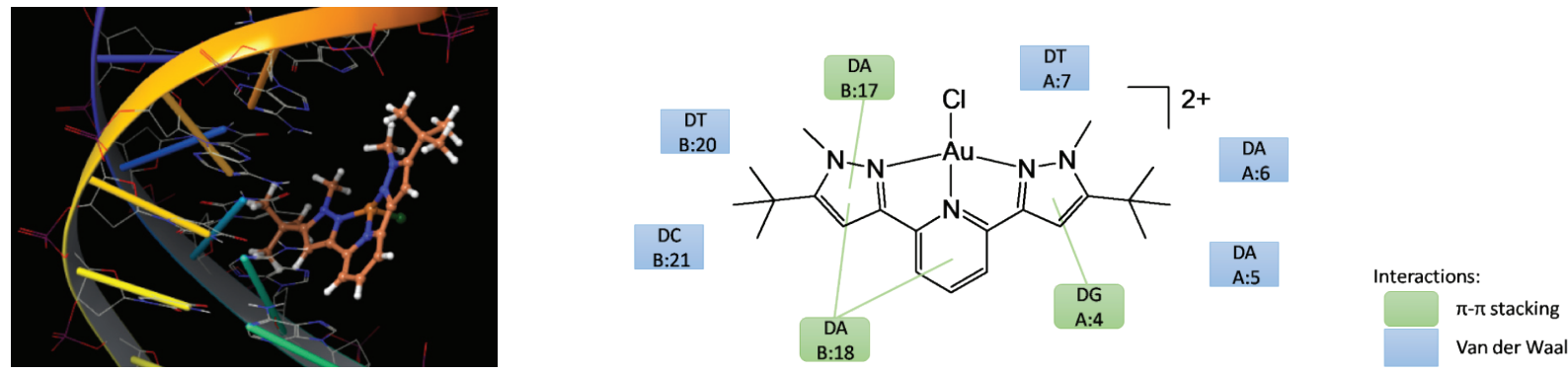

Complex 7
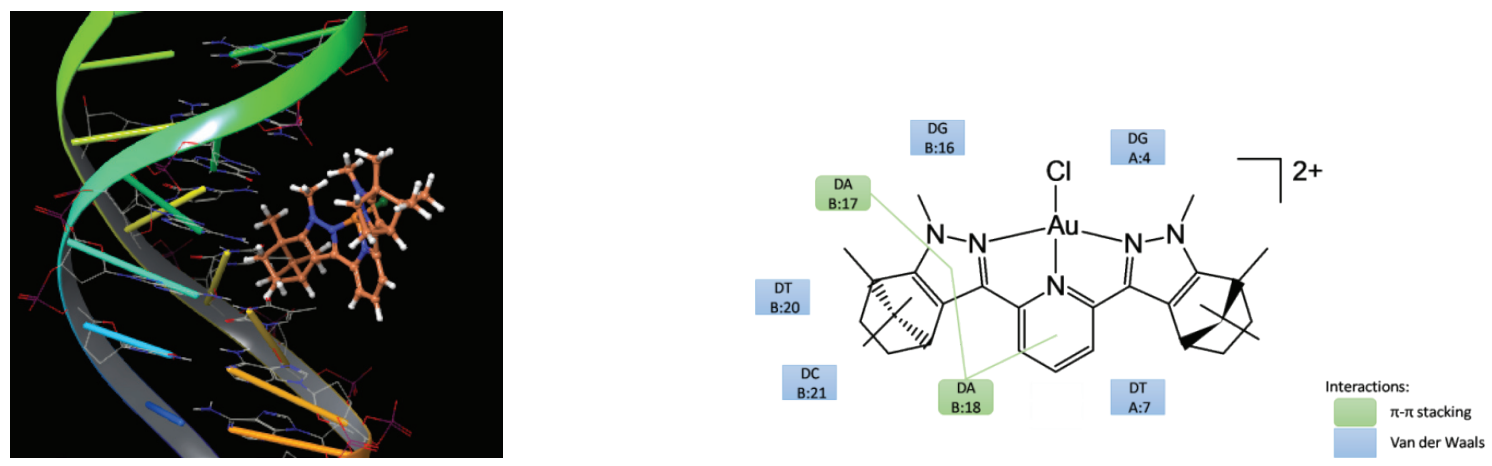

Figure 3. Visual representation of complexes 5-7 bound to 1BNA dodecamer and schematic representation of interactions. ${ }^{[34]}$

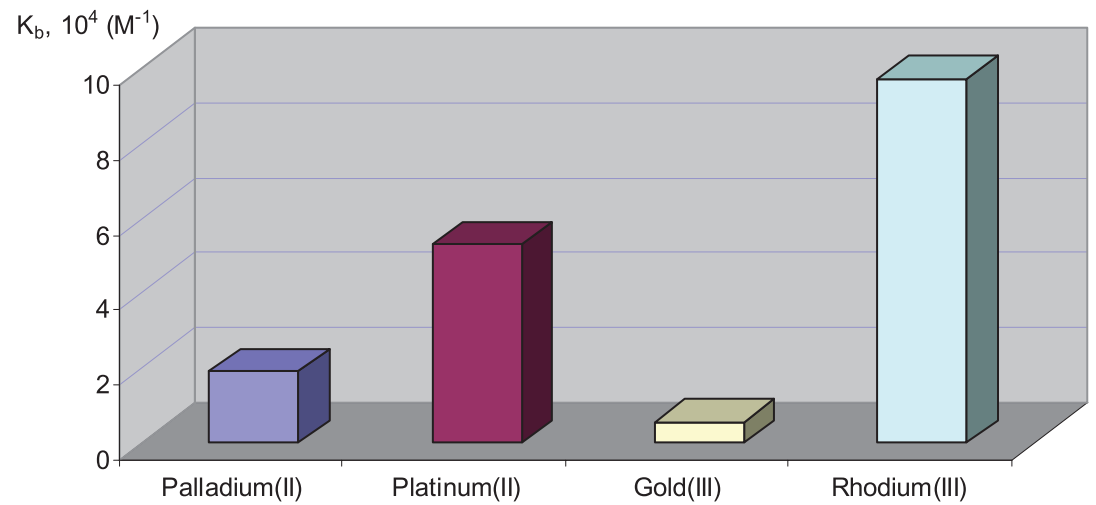

Figure 4. Comparison of $K_{\mathrm{b}}$ constants for different metal ion complexes containing $\mathrm{H}_{2} \mathrm{~L}^{t B u}$ ligand. 
Complex 1 showed the highest cytotoxicity on both tumor cell lines, HeLa and PANC-1. For example, $\mathrm{IC}_{50}$ values after $48 \mathrm{~h}$ of exposure were $13.7 \mu \mathrm{g} / \mathrm{mL}$ and $38 \mu \mathrm{g} / \mathrm{mL}$ for HeLa and PANC-1, respectively, but for cisplatin these values were $9 \mu \mathrm{g} / \mathrm{mL}$ and $16 \mu \mathrm{g} / \mathrm{mL} .^{[33]}$ Complex 2 showed several times higher $\mathrm{IC}_{50}$ values than $\mathbf{1}$, for both cancer cell lines. For complexes $\mathbf{3}$ and $\mathbf{4}$ it was found that they exhibit the strongest cytotoxic effect on HeLa cells at the highest concentration, while PANC-1 cells were less sensitive toward these complexes. Therefore, different sensitivity of the treated tumor cell lines indicates that these compounds could be potentially useful in therapy of certain types of tumors. The presented results may contribute to the development of new antitumor $\mathrm{Pd}(\mathrm{II}) / \mathrm{Pt}(\mathrm{II})$-based drugs and the finding of alternative cancer treatment procedures.

Table 3. In vitro anticancer activity of $\mathrm{Pt}(\mathrm{II})$ and $\mathrm{Pd}(\mathrm{II})$ complexes 1-4 on different cancer cell lines. ${ }^{[33]}$

\begin{tabular}{lcccccc}
\hline \multirow{2}{*}{ Cell line } & \multicolumn{5}{c}{$\mathrm{IC}_{50}(\mu \mathrm{M})$} \\
\cline { 2 - 7 } HeLa & $24 \mathrm{~h}$ & 60 & 240 & 90 & 80 & 26 \\
& $48 \mathrm{~h}$ & 13.7 & 83 & 57.1 & 70 & 9 \\
PANC-1 & $24 \mathrm{~h}$ & 67 & 360 & 410 & $>1000$ & 48 \\
& $48 \mathrm{~h}$ & 38 & 372 & 168 & 146 & 16 \\
\multirow{2}{*}{ MRC-5 } & $24 \mathrm{~h}$ & 45 & 240 & 78 & 240 & 180 \\
& $48 \mathrm{~h}$ & 33 & 180 & 70 & 140 & 43 \\
\hline
\end{tabular}

Recently, we have tested the cytotoxicity of $\mathrm{Au}(\mathrm{III})$ pincer complexes 5-7 in several cell lines derived from human cancers, i.e. lung carcinoma (A549), melanoma (A375), colon carcinoma (LS-174 and HCT 116), breast carcinoma (MDA-MB-231) and cervix carcinoma (HeLa), and in two cell lines derived from mice, i.e. colon carcinoma (CT26) and breast carcinoma (4T1). ${ }^{[34,42]}$ We then compared the obtained $\mathrm{IC}_{50}$ values, which are summarized in Table 4. The MTT results revealed that complexes 5-7 and cisplatin, show dose-dependent cytotoxic effects against all tested cancer cells. The most active complex proved to be $\mathbf{5}$ with $\mathrm{IC}_{50}$ values being up to $0.7 \mu \mathrm{M}$. The compound $\mathbf{5}$ emerged

Table 4. In vitro anticancer activity of Au pincer complexes 5-7 and cisplatin against different cancer cell lines.

\begin{tabular}{|c|c|c|c|c|c|}
\hline \multirow{2}{*}{ Cell line } & \multicolumn{4}{|c|}{$\mathrm{IC}_{50}(\mu \mathrm{M})$} & \multirow{2}{*}{ Ref. } \\
\hline & 5 & 6 & 7 & cisplatin & \\
\hline LS-174 & 11.2 & - & - & 24.4 & [34] \\
\hline A549 & 20.1 & - & - & 24.1 & [34] \\
\hline A375 & 13.1 & - & - & 23.1 & [34] \\
\hline $\mathrm{HeLa}$ & 1.3 & 3.4 & 5.7 & 26.7 & [42] \\
\hline MDA-MB-231 & 1.6 & 15.1 & 5.4 & 30.8 & [42] \\
\hline $4 \mathrm{~T} 1$ & 1.7 & $>100$ & 6.2 & 1.8 & [42] \\
\hline HCT116 & 0.7 & 53.9 & 4.1 & 1.6 & [42] \\
\hline СТ26 & 4.3 & 26.04 & 6.2 & 2.6 & [42] \\
\hline
\end{tabular}

as the most efficient cytotoxic agent against three human cancer cells HeLa, MDA-MB-231 and HCT116, and against $4 \mathrm{~T} 1 \mathrm{cell}$ line derived from mice, following a $72 \mathrm{~h}$ incubation period. The most prominent effect of complex $\mathbf{6}$ was noticed in HeLa cells with $\mathrm{IC}_{50}$ values of $3.4 \mu \mathrm{M}$. Similarly, following the same incubation period, the complex 7 significantly decreased the viability of three human cancer cells (HeLa, MDA-MB-231 and HCT116) and two cells derived from mice (4T1 and CT26). Complexes 5-7 were shown to induce apoptosis of HeLa cells by caspase-dependent mechanism. We have also shown that $\mathbf{5}$ induced perturbations of the cell cycle and led to apoptosis in human melanoma A375 cells. Additionally, complex $\mathbf{5}$ affected the level of reactive oxygen species (ROS) in the same cells. However, pre-treatment of A375 cells with NAC ( $N$-acetyl- $L$-cysteine) (ROS scavenger) reversed the effect of $\mathbf{5}$ on their survival. To sum up, the antitumor efficacy of $\mathrm{Au}(\mathrm{III})$ pincer complex $\mathbf{5}$ was in a good correlation with the kinetic reactivity and DNA binding affinity. Furthermore, we demonstrated that $\mathrm{Au}(\mathrm{III})$ pincer complexes showed the highest cytotoxicity with $\mathrm{IC}_{50}$ values up to $0.7 \mu \mathrm{M}$ for HCT116 cells, compared to analogous compounds of platinum, palladium and rhodium. ${ }^{[33-36,42]}$

All studied $\mathrm{Rh}$ (III) complexes were investigated on human colorectal cancer HCT-116 cells using an MTT assay. ${ }^{[35,36]}$ Compound $\mathrm{M}_{2} \mathrm{~L}^{*}$ showed the most significant effects with an $\mathrm{IC}_{50}$ of $80.01 \mu \mathrm{M}$ and $7.26 \mu \mathrm{M}$ after 24 and $72 \mathrm{~h}$ treatment. This anti-proliferative effect by $\mathrm{M}_{2} \mathrm{~L}^{*}$ was concentration and time dependent. In contrast, $\mathrm{H}_{2} \mathrm{~L}^{t \mathrm{Bu}}$ and terpy were not cytotoxic against HCT-116 cells under our laboratory conditions.

\section{Conclusion}

We have demonstrated that the rates of the substitution reactions of metallocomplexes with biologically relevant molecules can be controlled by the choice of the inert tridentate chelating ligands and metal ion, as well as by the chemical nature of the entering ligand. Generally, less sterically hindered complexes containing $\mathrm{H}_{2} \mathrm{~L}^{t \mathrm{Bu}}$ ligand exhibited higher kinetic reactivity compared to the corresponding compounds that are more sterically hindered which contain $\mathrm{Me}_{2} \mathrm{~L}^{\mathrm{tBu}}$ ligand. Moreover, the kinetics reactivity of the selected transition metal-based complexes depended also on the nature of the metal ions following the order of reactivity: $\mathrm{Au}(\mathrm{III})>\mathrm{Pd}(\mathrm{II})>\mathrm{Rh}(\mathrm{III})>\mathrm{Pt}(\mathrm{II})$ complexes. On the other hand, the $\mathrm{Pt}(\mathrm{II})$ pincer complexes were more reactive in the substitution reactions with $L$-met compared to the corresponding $\mathrm{Rh}(\mathrm{III})$ pincer complexes.

Also, in this review we have summarized the importance of studying interactions of DNA and BSA with complexes of several metal ions such as Pt(II), Pd(II), Au(III) and $\mathrm{Rh}(\mathrm{III})$. Comparing the $K_{\mathrm{b}}$ values obtained for the interactions of these complexes with CT-DNA, it can be seen that $\mathrm{Au}$ (III) complexes showed the lowest DNA-binding affinity $\left(K_{\mathrm{b}}=10^{3} \mathrm{M}^{-1}\right)$ what is opposite to their anticancer activity $\left(\mathrm{IC}_{50}=0.7 \mu \mathrm{M}\right)$. However, $\mathrm{Rh}(\mathrm{III})$ complexes exhibited a higher interaction with DNA but not so pronounced cytotoxicity. We suggested that DNA is not the primary target for selected $\mathrm{Au}(\mathrm{III})$ and $\mathrm{Rh}(\mathrm{III})$ pincer complexes. Among the complexes of various metal ions that we have described in the 
present review, it appeared that $\mathrm{Au}(\mathrm{III})$ pincer complexes are the most potent cytotoxic agents against the studied cancer cell lines. Complex $\mathbf{5}$ showed the highest cytotoxicity with $\mathrm{IC}_{50}$ of $0.7 \mu \mathrm{M}$ against HCT116 cells with apoptosis being the main mechanism of complex-induced cell death. Overall, we have demonstrated the potential of metal-based pincer type complexes as promising candidates for future pharmacological research. After the careful review of our works on Pt(II), $\mathrm{Pd}(\mathrm{II}), \mathrm{Au}(\mathrm{III})$ and $\mathrm{Rh}(\mathrm{III})$ complexes, it becomes clear that these complexes offer a promising approach to the development of new anticancer agents.

Acknowledgements. The authors gratefully acknowledge financial support from the Ministry of Education, Science and Technological Development of the Republic of Serbia (Agreement No. 451-03-68/2020-14/200122).

\section{References}

1. a) Alessio E. Bioinorganic Medicinal Chemistry. Germany: Wiley-VCH Verlag \& Co. KGaA, Weinheim, 2011; b) Rosenberg B., Camp L.V., Trosko J.E., Mansour V.H. Nature 1969, 222, 385-386.

2. Ndagi U., Mhlongo N., Soliman E.M. Drug Des. Dev. Ther. 2017, 11, 599-616.

3. Fanelli M., Formica M., Fusi V., Giorgi L., Micheloni M., Paoli P. Coord. Chem. Rev. 2016, 310, 41-79.

4. Sabine H.R., Sadler P.J. Drug Discovery Today 2009, 14, 1089-1097.

5. Petrović B., Jovanović S., Puchta R., Eldik van R. Inorg. Chim. Acta 2019, 495, 118953.

6. Kelland L. Nat. Rev. Cancer 2007, 7, 573-584.

7. Bugarčić D.Ž., Bogojeski J., Petrović B., Hochreuther S., Eldik van R. Dalton Trans. 2012, 41, 12329-12345.

8. Ahmad S. Polyhedron 2017, 138, 109-124.

9. Reedijk J. Eur. J. Inorg. Chem. 2009, 10, 1303-1312.

10. Ang W.H., Myint M., Lippard S.J. J. Am. Chem. Soc. 2010, 132, 7429-7435.

11. Bogojeski J., Bugarčić D.Ž., Puchta R., van Eldik R. Eur. J. Inorg. Chem. 2010, 34, 5439-5445.

12. Arsenijević M., Milovanović M., Jovanović S., Arsenijević N., Simović M.B., Gazdić M., Volarević V. J. Biol. Inorg. Chem. 2017, 22, 807-817.

13. Bugarčić D.Ž., Bogojeski J., Eldik van R. Coord. Chem. Rev. 2015, 292, 91-106.

14. Ć́oćić D., Jovanović S., Nišavić M., Baskić D., Todorović D., Popović S., Bugarčić D.Ž., Petrović B. J. Inorg. Biochem. 2017, 175, 67-79.

15. Kapdi A.R., Fairlamb I.J. Chem. Soc. Rev. 2014, 43, 47514777.

16. Lazarević T., Rilak A., Bugarčić D.Ž. Eur. J. Med. Chem. 2017, 142, 8-31.

17. Rilak Simović A., Masnikosa R., Bratsos I., Alessio E. Coord. Chem. Rev. 2019, 398, 113011.
18. Ma L.D., Wang M., Mao Z., Yang C., Ng T.C., Leung H.C. Dalton Trans. 2016, 45, 2762-2771.

19. Timerbaev A.R., Hartinger C.G., Aleksenko S.S., Keppler B.K. Chem. Rev. 2006, 106, 2224-2248.

20. Ott I. Coord. Chem. Rev. 2009, 253, 1670-1681.

21. Romero-Canelon I., Sadler P.J. Inorg. Chem. 2013, 52, 12276-12291.

22. Bindoli A., Rigobello M.P., Scutari G., Gabbiani C., Casini A., Messori L. Coord. Chem. Rev. 2009, 253, 1692-1707.

23. Cattaruzza L., Fregona D., Mongiat M., Ronconi M., Fassina A., Colombatti A., Aldinucci D. Int. J. Cancer 2011, 128, 206-215.

24. Ronconi L., Aldinucci D., Dou Q.P.D. Med. Chem. 2010, 10, 283-292.

25. a) Barry P.E.N., Sadler P.J. Chem. Commun. 2013, 49, 5106-5131; (b) Ronconi L., Sadler P.J. Coord. Chem. Rev. 2007, 251, 1633-1648.

26. Dilruba S., Kalayda V.G. Cancer Chemoth. Pharm. 2016, 77, 1103-1124.

27. Rijt van H.S., Romero-Canelón I., Fu Y., Shnyder D.S., Sadler J.P. Metallomics 2014, 6, 1014-1022.

28. Cutillas N., Yellol S.G., Haro C., Vicente C., Rodriguez V., Ruiz J. Coord. Chem. Rev. 2013, 257, 2784-2797.

29. Bear L.J., Howard A.R., Korn E.J. Inorg. Chim. Acta 1979, 32, $123-126$

30. Halcrow M.A. Coord. Chem. Rev. 2005, 249, 2880-290.

31. Willison S.A., Jude H., Antonelli R.M., Rennekamp J.M., Eckret N.A., Bauer J.A.K., Connick W.B. Inorg. Chem. 2004, 43, 2548-2555.

32. Morales-Morales D., Jensen C.M. The Chemistry of Pincer Compounds. Elsevier, 2007.

33. Ćoćić D., Jovanović S., Radisavljević S., Korzekwa J., Scheurer A., Puchta R., Baskić D., Todorović D., Popović S., Matić S., Petrović B. J. Inorg. Biochem. 2018, 189, 91-102.

34. Radisavljević S., Bratsos I., Scheurer A., Korzekwa J., Masnikosa R., Tot A., Gligorijević N., Radulović S., Rilak Simović A. Dalton Trans. 2018, 47, 13696-13712.

35. Milutinović M.M., Bogojeski J.V., Klisurić O., Scheurer A., Elmroth S.K.C., Bugarčić D.Ž. Dalton Trans. 2016, 45, 15481-15491.

36. Petrović A., Milutinović M.M., Petri E.T., Živanović M., Milivojević N., Puchta R., Scheurer A., Korzekwa J., Klisurić O.R., Bogojeski J. Inorg. Chem. 2019, 58, 307-319.

37. Djeković A., Petrović B., Bugarčić D.Ž., Puchta R., van Eldik R. Dalton Trans. 2012, 41, 3633-3641.

38. Eryazici I., Moorefield N.C., Newkome R.G. Chem. Rev. 2008, 108, 1834-1895.

39. Liu H.Q., Cheung T.C., Peng S.M., Che C.M. J. Chem. Soc., Chem. Commun. 1995, 1787-1788.

40. Messori L., Marcon G., Innocenti A., Gallori E., Franchi M., Orioli P. Bioinorg. Chem. Appl. 2005, 3, 239-253.

41. Shi P., Jiang Q., Zhao Y., Zhang Y., Lin J., Lin L., Ding J., Guo Z. J. Biol. Inorg. Chem. 2006, 11, 745-752.

42. Zarić M.M., Čanović P.P., Stanojević Pirković M., Knežević S.M., Živković Zarić R.S., Popovska Jovičić B., Hamzagić N., Simović Marković B., Marković N., Rilak Simović A. Vojnosanit. Pregl. 2020, https://doi.org/10.2298/VSP190507002Z. 